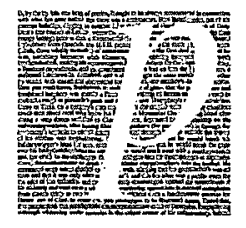

\title{
Snakecharmers and Nascent Oxygen: André Breton and the American Marvelous
}

\author{
Christopher Winks
}

\section{New York University}

\begin{abstract}
$\mathrm{A}^{\mathrm{s}}$ s André Breton and his fellow surrealists never tired of affirming, the transformative surrealizing impulse long antedated the surrealist moment (hence the movement's interest in developing and reconfiguring a force-field of multiple traditions or anti-canons). To some degree, surrealism's truth lay outside the movement proper, and a fortiori outside individual creative works, which while they could approximate certain dreams, obsessions, or lived moments, were but intimations of a greater revelation. Breton concludes his final edition of Manifestes du Surréalisme with a 1953 speech, "Du Surréalisme en ses oeuvres vives," in which he declares, "[il s'agissait d]e rien moins que de retrouver le secret d'un langage dont les éléments cessassent de se comporter en épaves à la surface d'une mer morte" $(1962,335)$.

Surrealism can best be described in terms of its constant search, articulated from Breton's 1924 Manifeste du surréalisme onward, for the marvelous, that gold of time that dwelled, no longer in the philosopher's stone, but in the unexpected turning points and encounters of daily life. While "le merveilleux, je le répète, est partout, de tous les temps, de tous les instants" (Péret 1960, 16), under present "civilized" conditions, it
\end{abstract}


can only be apprehended in momentary, revelatory eruptions. The poetic moment is that which seeks through the imagination's alchemy to translate such revelations into a language that, in the moment of communication, awakens/inspires similar revelations in others. If, as Rimbaud said, "la vraie vie est ailleurs," the marvelous, which is inextricably linked to even the most impoverished here-and-now, is the doorway opening out onto that life:

Le Merveilleux exprime le besoin de dépasser les limites imposées, imposées par notre structure, d'atteindre une plus grande beauté, une plus grande puissance, une plus grande jouissance, une plus grande durée. (...) Mais le Merveilleux est moins encore la tension extrême de l'être que la conjonction du désir et de la réalité extérieure. (Mabille 1977, 69-70)

The ferocity of many of the surrealist polemics, as well as the practice of scandal and provocation, stemmed from a desire to clear away - exorcise - the repressive cultural encrustations weighing down contemporary intellectual and social life, so that when the marvelous manifested itself, it would be understood with greater clarity by a greater number. Equally essential was the location within social/artistic history of a constellation of values capable of passing conclusive and transcendent judgment on the existing order.

Assimilating the lessons of surrealism to those of modern art as a whole, Pierre Mabille observed: "Il ne s'agissait pas moins que de condamner tout l'héritage européen classique, de rejeter l'ensemble des valeurs traditionnelles, de remettre en question les jugements et les opinions qui semblaient définitivement établis et cela dans tous les domaines: métaphysiques, philosophiques, esthétiques et sociaux" $(1981,53)$. The thoroughgoing nature of such a critique implied that the search for an alternative anti-philosophy could not be confined to a strictly "Western" context; the First World War had made it devastatingly clear that the problems of the age transcended borders and national cultures, in turn casting new light on those cultures outside of Europe which, having been plundered of much of their material and some (but not all) of their spiritual wealth, had been consigned to a place on the capitalist "periphery."

To a large extent, the "modern spirit" was formed by the complex interactions between the respective cultures of the colonizers and the colonized. Taking as a starting point Tzvetan Todorov's statement that the modern era begins with Columbus's 1492 landfall, it is possible to see modernity as a site of struggle between an expanding world (capitalist) system and its attendant values, and the theoretical and practical forces of critique and resistance generated by this expansion. For example, the French Revolution was decisively (albeit briefly) radicalized by the 1791 Haitian Revolution (which in turn later gave protection and support to Simón Bolívar's campaign for Latin American independence); just as the system of slave labor in the Caribbean had fueled the machine of a nascent capitalism, so also did the abolition of this system herald a possible transcendence of the limits of a strictly bourgeois revolution. The self-emancipated Africans, taking seriously the universalist claims of the liberty-equality-fraternity triad, fought with a dedication that was the envy of their "republican" French opponents. Inspired by their example, William Blake inveighed 
against slavery in his poetry, and William Wordsworth paid tribute to Toussaint L'Ouverture. Many years later, in an era awakening from the dead weight of petrified revolutions and victorious counter-revolutions, Pétrus Borel, one of surrealism's ancestors, declared in 1831, "Je suis républicain parce que je ne puis pas être Caraibe."

Given this mutually reinforcing dynamic of metropolitan and peripheral critique, it would be oversimplifying to view the early 20th-century European artistic avant-garde's use of African, Asian, and Pre-Columbian motifs solely in terms of appropriation of stolen goods. Such a view, while tempting, ignores the liberatory effects that so-called "primitive" art had on creative expression-effects that can in no way be considered as second-hand or plundered. (And in the case of Picasso, who came from the most "African" of European countries, the question of authenticity or lack thereof is not so easily resolved). Those who were among the first to extol the qualities of "primitive" art were resolutely opposed to the contemporary cultural mainstream: Blaise Cendrars, Hugo Ball, Tristan Tzara, Carl Einstein. However, except for Cendrars (in his pioneering Anthologie nègre) and Einstein (in his still-ignored study Negerplastik), the Cubists and particularly the Dadaists tended to use "primitive" art and poetries for effect rather than concentrate on deeper meanings. The presence of Maori and African poems in a compilation like the 1920 Dada Almanach is intended less to astonish than to provoke or inspire nervous laughter at their "meaninglessness."

The initial focus of Surrealism was less on the "primitive" marvelous than on a specifically Parisian milieu. Its frame of reference, for all its antinomianism, was impeccably European: the cinema, chateaux, brothels, the wireless, Romantic literary traditions, Rousselian impressions of Africa... And yet, there was the paramount influence of the Uruguayan-born Ducasse/Lautréamont, as well as the cry to an imagined (and imaginary) Orient that concludes Breton's 1924 "Introduction au discours sur le peu de réalite,", reminiscent of Baudelaire's "Anywhere out of this world!," to show that surrealism could not remain confined to geographical coordinates any more than it could to mental ones.

Within a year of the publication of the Manifeste du surréalisme, the group had made common cause with the Communist intellectuals of the Clarte group to denounce the French colonial repression of the Moroccan revolt led by Abd el-Krim, as well as the servile declarations of support for this policy penned by several official intellectuals. Breton would later (in 1934, shortly before his final break with the Communist Party) cite this 1925 denunciation, "La Révolution d'abord et toujours" as a crucial stage in the evolution of the movement away from a facile "insurrectionary" line towards an engagement with a wider, historical problematic: "Surrealist activity, faced with a brutal, revolting, unthinkable fact, was forced to ask itself what were its proper resources and to determine their limits; it was forced to adopt a precise attitude, exterior to itself, in order to face whatever exceeded these limits" $(1978,117)$.

Following this outward turn, surrealism was rewarded with the autonomous participation of the Légitime défense group of Martinican students in Paris, who helped to render the anti-colonial content of surrealist agitation more precise. The 1932 mani- 
festo "Murderous Humanitarianism," published in Nancy Cunard's Negro Anthology, is a remarkable polemic which still retains its currency:

In the Antilles, as in America, the fun began with the total extermination of the natives, in spite of their having extended a most cordial reception to the Christopher Columbian invaders. Were they now...to set out empty-handed for home? Never! So they sailed on to Africa and stole men. These were in due course promoted by our humanists to the ranks of slavery.... (Breton et al 1978, 326)

Additionally, many Latin American writers living in Paris during the 1920's and 1930's came under the influence of surrealism and used its insights to explore, both in exile and at home, their countries' richly imaginative folk traditions; Miguel Angel Asturias, Lydia Cabrera, Alejo Carpentier. In 1929, Benjamin Péret went to Brazil where he spent two years organizing a Trotskyist-oriented group before being expelled from the country.

However, surrealist thought itself bore few evident traces of critical engagement with other cultures. Indeed, of the two crucial turning points in surrealism's mature development - the break with the Communist Party and the American exile of Breton and Péret among others - it is possible to affirm that had it not been for the latter event, surrealism could very well have stagnated in sterile intellectual isolation. Without in any way minimizing the political and personal risks and hardships involved in the surrealists' displacement from Europe to the Americas, in many respects it was the best thing that could have happened to the movement. Not only did they avoid succumbing to the nationalist, Stalino-Christian wartime virus that Péret would term "le déshonneur des poètes," they were able to look beyond the immediate situation of the war towards the intellectual and spiritual forces that would emerge from its wreckage. An indication of a probable emancipatory source of such regeneration emerges in a dream recounted by Breton during a 1941 interview with Charles Henri Ford:

As for myself, I don't remember having dreamed of Hitler: I don't think he enters into my mythology. (...) In an ambitious way, not usual with me, I dreamed while in the throes of a great exaltation at Ciudad Trujillo that I was Zapata, making ready with my army to receive Toussaint L'Ouverture the following day and to render him the honors to which he was entitled. $(1978,200)$

Breton's dream anticipates an encounter between representatives of the two great sources of a specifically American culture: the Indians and the Africans. That the dream should occur in Ciudad Trujillo - a city named after its then-ruling fascist dictator who nonetheless enjoyed the protection of U.S. democracy - is noteworthy in that the dreamer is on that part of the island of Hispaniola which was stolen from the Haitian revolutionaries; the "honors" which Toussaint is to receive from Breton-Zapata are those pertaining to the restoration of his patrimony. Insofar as Breton identifies in his dream with Zapata, the incarnation of the Mexican Revolution, the first great revolution of the 20th century, he locates himself at the crossroads of the "primitive" and the "modern" and reveals the ground of their fundamental unity in the revolutionary moment. Breton's personal rejection of any possible oneiric function to be played by 
Hitler comes in the context of an evaluation of those collective and individual European dreams that reveal an obsession with the Nazi leader, and echoes the great (and greatly misunderstood) aphorism of Karl Kraus, "Mir fällt zu Hitler nicht ein." A Europe that prefers to indulge in waking dreams of Hitler instead of fighting him has irremediably fallen prey to an irrationalism which can only be exorcised by realized New World dreams of freedom.

From their American sojourn, Breton and Péret, each in his own way, derived a renewed concern with myth and a revitalization of the all-important concept of the marvelous in light of its relevance to "primitive" thought. Paradoxically, in view of the European origins of the movement, surrealism had more lasting effects on the poetry of the Americas than anywhere else: here, it had room to develop autonomously, at some remove from the hothouse world of the Parisian avant-garde, and Breton not only welcomed this independence but - particularly in the case of Aimé Césaire-encouraged it.

Breton himself had traveled to Mexico in 1938, ostensibly to give a series of lectures but also to visit and confer with Leon Trotsky in his Coyoacán exile. Shortly after his arrival, he granted an interview to the Honduran journalist Rafael Heliodoro Valle, in which he said among other things that "Aside from everything I have said, Mexico tends to be the surrealist place par excellence. I find Mexico surrealist in its geography, its flora, in the dynamism conferred upon it by its mixture of races, as well as in its highest aspirations" (Baciu 174, 102; my translation).

While the label of "surrealist" may work for an individual author, it is less fortunate to confer it on a country, not to mention a culture. This statement is the all-too-easy judgment a tourist makes: reductive and certainly ethnocentric, with little concern for the complexities of Mexico's history or the nature of its "aspirations," be they high or low. Yet Breton was also endowed with keenly intuitive capacities of observation which enabled him to transcend his first superficial impressions and give eloquent testimony to everything about Mexico that moved him, from the persistence of the revolutionary spirit, in great contrast to a Europe threatened by Fascism and Stalinism ("Du moins reste-t-il au monde un pays où le vent de la libération n'est pas tombé" (Breton $1967,34)$, to the endurance of its mythical past:

Impérieusement le Mexique nous convic à cette méditation sur les fins de l'activité de l'homme.... Le grand message des tombes, qui par des voies insoupçonnables se diffuse bien mieux qu'il ne se déchiffre, charge l'air d'électricité. Le Mexique, mal réveillé de son passé mythologique, continue à évoluer sous la protection de Xochipilli, dieu des fleurs et de la poésie lyrique et de Couatlicue, déesse de la terre et de la mort violente... Ce pouvoir de conciliation de la vie et de la mort est sans aucun doute le principal appât dont dispose le Mexique. (1967, 35-36)

Having written eight years earlier in his Second manifeste du surréalisme "Tout porte à croire qu'il existe un certain point de l'esprit d'où la vie et la mort...cessent d'être perçus contradictoirement" $(1962,154)$, Breton had now encountered in Mexico this point as an aspect of a shared collective (mythic) consciousness, which echoed in the reverberations of social revolution as well as in the popular art of Posada and the 
experimental photography of Manuel Álvarez Bravo, whose work Breton singled out for especial praise. And the existence of this point as a dialectical reconciliation and surpassing of the previously separate, externally defined and imposed categories of "primitive" and "modern" would subsequently become central to Breton's thought.

In a 1945 speech in Haiti, Breton defined the importance of the "primitive" for surrealism and for modern thought as a whole:

...in the essential development of surrealism... we have found ourselves linked from the beginning with 'primitive' thought, which remains less alien to you than to us. (...) In periods of great social and moral crisis, I believe it is indispensable that we inquire into primitive thought, to rediscover the fundamental aspirations, the incontestably authentic aspirations, of mankind. $(1978,259)$

On the immediate level, those artifacts and poetic records that, through the emerging discipline of ethnography, were being made available to the denizens of "civilization," gave proof of a strongly poetic imagination that, according to the surrealists, was steeped in the same primal sources of inspiration that "automatic writing" had intended to tap. If, as Benjamin Péret affirmed in the title of an article, "La pensée est UNE et indivisible," this implied the artificiality if not the utter nullity of all antinomies between "logical" and "pre-logical," "primitive" and "civilized." The cultural creations of so-called "savages," then, bore witness to a different way of conceiving reality; the world of the "real" and the world of "myth" tended to interpenetrate.

In an interesting study, the Martinican writer and sometime surrealist fellow-traveler Jules Monnerot, while criticizing ethnography as a particularly refined form of exoticism, considered attempts like those of Lévy-Bruhl to establish some kind of "primitive mentality" as more revealing of their proponents than of the objects of their study: "par empreinte en relief du civilisé se forme l'image en creux du primitif et les traits dominants de celui-ci révèlent les manques de celui-là. En sorte qu'on peut tenir la 'mentalité primitive' pour une projection vaniteuse et nostalgique, un négatif de la nôtre" (Monnerot 1945, 98). Against what Monnerot called "l'impérialisme de la vie ordinaire," so-called "primitive" societies revealed, in a manner comparable to that of the surrealists, that myths, dreams, wonders, prophecies, and encounters fulfilled every criterion of social utility inasmuch as they enabled people to live.

Breton correctly viewed modern art's coming to terms with the "synthèse de perception sensorielle et de représentation mentale" $(1969,248)$ characteristic of "primitive" art as a process rather than something to which all well-intentioned people could gain instant access. In his first (1941) article on the Cuban artist Wifredo Lam, Breton describes the "modern eye" as having "...gradually taken in the endless variety of those objects of so-called 'savage' origin and their sumptuous display on the lyrical plane, and aware, at last, of the incomparable resources of the primitive vision, has fallen so in love with this vision that it would wish to achieve the impossible and wed it" (1972b, 169). That Breton should speak of the modern artist's quest to incorporate primitive world-views as an "impossibility" originating in a profound nostalgia indicates the problematic nature of the "civilized" artist's relationship to the primitive. For this artist, it is not a matter of assimilating the primitive tout court but of defining a 
common terrain of activity with it. And for this to happen, the artist must be an interlocutor, not a missionary. How Breton himself handles this complex task is the subtext of his important and profound record of his 1941 voyage to the Caribbean, Martinique charmeuse de serpents, which is comparatively little-known and rarely discussed as a whole (although the essay on Aimé Césaire, "Un grand poète noir," has achieved recognition as the preface to the Martinican's Cahier d'un retour au pays natal). In fact, many of Breton's future preoccupations with myth and the sacred, often dismissed as the product of personal defeat and irrelevance, find their sources here; although the book was not published until 1948, it is composed of texts written between 1941 and 1943. Additionally, the circumstances in which these texts were composed testify to the creative power of chance to transform the most unpromising situation into a life-changing revelation: had the Capitaine-Paul-Lemerle, transporting refugees, Breton among them, from Vichy France to the Americas, not been forced to land at Martinique; had Breton, upon his provisional liberation from the Lazaret detention camp, not decided to enter a Fort-de-France haberdashery to buy a ribbon for his daughter, thereupon encountering the copy of Tropiques which would lead him to Césaire's work.

Owing to the atmosphere of personal and historical crisis in which it gestated, Martinique charmeuse de serpents transcends the genre of touristic "travel narrative" to which its title -a fusion of the island's name with the title of a Henri Rousseau painting - appears to confine it. What is at work is a dual process, or rather a process of doubling, manifested not only in the visual and verbal collaboration of the painter Andre Masson, but in the structural and poetic perspective adopted in the book, which oscillates between celebration of the island's profuse natural beauty and a denunciation of the colonial degradation to which this beauty has been submitted: "Aussi avons-nous été conduits, dans les pages qui suivent, à faire une part au langage lyrique, une autre au langage de simple information. Nous avons été follement séduits et au même temps nous avons été blessés et indignés" (Breton 1972a, 8; all subsequent references incorporated into the text of this essay). By exploring the practice of the double voice, Breton and Masson unconsciously replicate a stylistic device which in recent years has been specified (particularly by Henry Louis Gates, Jr.) as characteristic of African-American oral and written traditions. Themselves at the crossroads of transition, in a liminal condition between worlds, Breton and Masson re-enact the drama of Legba, the deity of transition and interpreter of worlds and words. They do not seek to appropriate but to understand.

In "Le Dialogue Créole entre André Breton et André Masson," poet and painter confront the issue of exoticism, which had first been broached by the surrealists in the "Murderous Humanitarianism" broadsheet: "...the whole object of our modern travel lust is of use only in entertaining that class of blasé client sly enough to see an interest in deflecting to his own advantage the torrent of those energies which soon-much sooner than he thinks-will close over his head" (Breton et al 1978, 327). They discuss the wild beauty of the Martinique environment as the materialized fulfillment of the surrealist landscapes created in a far less luxuriant Europe, and postulate that artists 
like Gauguin fled to the tropics because they knew that floral surroundings adequate to their desires were to be found outside their native land. "Mais qu'entendre par exotisme? La terre toute entière nous appartient. Ce n'est pas une raison parce que je suis né à proximité d'un saule pleurer pour que je doive vouer mon expression à cet attachement un peu court" (21).

Undeniably, in the Western world travel has meant reducing different cultures to a consumable "exoticism" whose ground has been cleared in advance by imperialist predation. But it does not follow that the desire to go elsewhere in search of the unusual or extraordinary is eternally condemned to replicate the colonizing gaze. If "la terre tout entière nous appartient," this belonging cannot be interpreted in a narrowly possessive sense but as an affirmation of a fundamental human desire to experience unknown and dreamt-of surroundings (a desire which colonialism and imperialism have effectively exploited to their own ends), whether through mental or physical voyages. Breton and Masson cite the example of Henri Rousseau, who according to some drew his inspiration from a voyage to Mexico and according to others never left France and relied exclusively on fantasy in painting his jungle landscapes. Regardless of what the "truth" may have been, Rousseau's landscapes leave the canvas and come alive for them in Martinique, testimony to a greater human enigma:

Si Rousseau n'avait pas bougé de France, il faudrait donc admettre que sa psychologie de primitif lui a découvert des espaces primitifs entiers conformes à la réalité. Il y aurait donc, par-delà tous les obstacles posés par la civilisation, une communication mystérieuse, seconde, toujours possible entre les hommes sur la base de ce qui les a unis originellement, et divisés. (23-24)

Thought and the imagination that propels it are here conceived in relation to a cross-cultural communicative nexus; in Rousseau's case, his own "primitive" psychology renders him more accessible to a spatial-topographic dimension that exists both in his imagination and in a "reality" of which he is the unconscious medium. Those dwelling within civilization must dream their nature before discovering it; those who have managed to elude civilization's encroachment —-so-called "primitives"- find themselves always already there, in a "forest of signs."

In the Caribbean, to speak of the forest is invariably to speak of history as well as spirit. For while the forest is the dwelling of the spirits (cf. Wifredo Lam's The Jungle); it is also the place of refuge for slaves running away from that supreme expression of "civilization," the plantation (which, as C.L.R. James and others have pointed out, was at its origins less a feudal aberration than a model of proto-capitalist social relations). The forest is therefore populated with memories of revolt. "Les mornes," "el monte" - these are sacred spaces where cultures can be reconstructed and placed in direct relation with their remembered social imaginary. Breton and Masson are, at least on a conscious level, unaware of the deeper significance of the Caribbean forest, but they are not insensible to its pull: "...là toutes les formes se confrontent et tous les contrastes s'exaltent. Au coeur de la foret, que j'aime cette expression!" (30). And yet they know they are not of it: "Nous croyons pouvoir nous abandonner impunément à la forêt et 
voilà tout à coup que ses méandres nous obsèdent: sortirons-nous de ce vert labyrinthe?" (33).

In a 1951 article, Pierre Mabille, who himself spent many years in the Caribbean, particularly in Haiti, both deepens and corrects Breton and Masson's observations:

...je ne puis penser aux noirs sans que l'image de la forêt ne s'impose à moi comme une obsession. (...) Le langage, confondant le tout et la partie, évoque fréquemment le coeur de la forêt en lui donnant sans nul doute le sens de "coeur de l'arbre," de centre. Mais, précisément, la forêt n'a point de centre, celui-ci est partout et nulle part. (...) Etudier le Vaudou, c'est précisément s'enfoncer dans la forêt et affronter ses pièges. (...) [C]'est au labyrinthe qu'invariablement on songe dès qu'on tente de pénétrer le Vaudou. (Mabille 1981, 8-9)

On the basis of Mabille's insight, it is possible to measure the real limits of Breton's apprehension of the "primitive" in general and Afro-Caribbean-Indian cultures in particular. Breton and Masson begin by attaching themselves to the illusory notion that the Caribbean forest has a heart or fixed center, whereas, as Mabille points out, this heart is everywhere in general and nowhere in particular. This belief, founded as it is on their own knowledge of the less extensive (because cleared away by civilization) forest expanses in Europe, quickly exposes its limits when the labyrinthine quality of the Martinique forest imposes itself. The two friends must search for an exit, and the irony of their position is not lost on them:

—J'y vois le gage même d'une délivrance. Oui, nous nous sommes épris de la force végétale et pourtant le besoin impérieux que nous avons éprouvé de nous entretenir des formes régulières dans un lieu de la nature où justement l'informe, je veux dire le manque du cadre, semble prédominant, quoi de plus significatif? (34)

What Breton and Masson are turning away from is precisely the moment of possession, of losing oneself in order to find oneself on a deeper level, integral to "primitive" religious practices. Not long afterward, Breton admitted, "Sans doute y a-t-il trop de nord en moi pour que je sois jamais l'homme de la pleine adhésion" (1962, 337). It is worth recalling that during the famous "époque des sommeils," when Robert Desnos (among others) experimented with states of possession, it was Breton who took the responsibility of forcibly pulling Desnos back from the brink of what he feared would become insanity; later in life, Breton would declare, "[J]e continue à croire que sur cette voie, passé outre à une certaine limite, la désintégration menace" (1970, 170). However true this judgment may have been in the context of an advanced capitalist society, where the pressures of life, for better or worse, are of a different order from those in a Haitian hounfort, Breton's diffidence nonetheless prevented him from discussing spirit-possession in Haiti in terms of a collective ritual, at once secular and sacred, linked to daily life and yet beyond it, a structured communion with the marvelous.

Breton was honest and lucid about his reticence and relative incomprehension; when speaking of his visits to Haitian vaudou ceremonies, to which he was escorted by Pierre Mabille, he wrote: 
Le pathétique des cérémonies vaudou m'a trop durablement assailli pour que, des persistantes vapeurs de sang et de rhum, je puisse prétendre à en dégager l'ésprit générateur et à en mesurer la réelle portée. Il ne me fut donné que de m'imprégner de leur climat, de me rendre perméable au déferlement des forces primitives qu'elles mettent en oeuvre. $(1970,200)$

This gives evidence of a certain failure of Breton's own conceptual and even poetic vocabulary (as reflected in his omission of the customary quotation marks around the word "primitive"). In fact, his compulsion to account for what he saw within the framework of his personal knowledge leads him to compound this error: he describes a subsequent discussion with Mabille where both men tried to assimilate these ecstatic moments to cases of hysteria at the Salpétrière, even speculating that these possessions were not entirely African-derived in their style and may well have been introduced to the island by the 18th-century occultist Martinez de Pasqually. Mabille himself, although more informed, equates the mounting of the human "horse" by the loa with the artist's moments of inspiration, describing such incidents in terms of "un mécanisme inconnu...qui est ressenti comme une voix, comme une force qui parle en eux, les pousse, les pénètre et les fait se mouvoir à leur insu" (Mabille 1981,69). Close, but not the whole story.

In his own pioneering (1928) study of Vaudou, the Haitian scholar Jean Price-Mars availed himself of a variety of psycho-scientific methodologies and vocabularies to explain the phenomenon of trance-possession. Rejecting a comparison with hysteria as insufficiently applicable from an etiological standpoint, Price-Mars determined that "...the voodooistic crisis is a mystical state characterized by the delirium of theomaniac possession (which) determines automatic acts and is accompanied by disorders of (kines)thesia... 'The affected person is conscious of formulating word for word and phrase by phrase a thought that is foreign to him. Somebody speaks inside him"" (1990, 124-125).

In other words, the trance state obeys in its inner mechanisms as well as its outward movements and semblances precisely that visionary condition aspired to and advocated by surrealism since its origins -only in this case, it is the expression of a community forged in resistance to an imposed "civilization," which it circumvents via syncretism. Here, the "impossibility" of which Breton spoke in relation to "wedding the primitive" reappears in Breton's own thought, as if to indicate that surrealism could only attain an approximate understanding of the real sophistication and grandeur of the "primitive's" mental and artistic universes. In this connection, it should be added that the people with whom Breton established important or lasting relationships in the Americas were not "primitives" in either the economic or cultural sense, but sophisticated, university-trained intellectuals. (Péret, on the other hand, lived with Amazonian Indian peoples for several months during the late 1950's; unfortunately, a promised narrative of that stay never materialized.) Thus, in order to examine the actual processes through which the "civilized" enter into trance-possession, it will be necessary to undertake a comparative study of the (very different) cases of Antonin Artaud 
among the Tarahumaras and Maya Deren in Haiti (both of whom, incidentally, were strongly influenced by surrealism).

However, it is also important to emphasize anew the ambivalence with which Breton (and Masson) approached the task of translating the Caribbean presence into their respective poetic languages. Indeed, no one enters upon a new terrain without hesitation, and Breton deftly preserves the tentative nature of his explorations (and the presiding presence of his native instructors in this new reality) in the series of prose poems "Des Epingles Tremblantes," whose evanescent, sketch-like qualities convey the traveler's gradual immersion in the island's history, with its colonial overlay scarcely concealing the rebellious beauty simmering beneath: "Sous l'étal miroitant à l'infini, dans l'ombre s'amoncellent, gorgées de roses rouges et roses, les conques vides de lambis dans lesquelles fut sonnée la révolte noire très sanglante de 1848" (1972a, 41). And the concluding poem, "La Carte de l'Ile," lets the island's geography speak for itself: it is a catalogue of names that concludes, significantly, with a series of "mornes."

The centerpiece of the book, "Eaux troubles," is for Breton an unprecedented foray into what for lack of a better word could be called "journalism" of a muckraking sort. Here, Breton investigates not only the conditions on board the Capitaine-Paul-Lemerle but the oppressive misery of colonial Martinican society itself. He identifies the most powerful people in town by name and describes in detail their exploitative and nepotistic practices, their suborning of the justice system, and their enthusiastic complicity with the Petainist regime. Because Breton was moved by the beauty of Martinique, he felt compelled to expose its real (socially imposed) ugliness even if it meant departing from his customary style of discourse, so long as the poetic truth of the island could emerge in greater relief against the sordid impositions of the colonial administration. As he put it at the conclusion of the piece, "...ce qui est lésé et défié par de telles moeurs est de trop d'importance pour que je m'avise d'y mêler la poésie imprescriptible de l'île et de prêter à ceux qui la défigurent ne fût-ce que l'ombre du parfum de ces forêts." (88).

In the poetry of Aimé Césaire, Breton encounters the native voice who will speak within a shared surrealist tradition, but because he does autonomously and on the basis of his own experience as a colonized man, he extends and deepens that tradition. While Breton welcomes a kindred spirit - "je l'éprouvai tout le prix...de le savoir entre tous un être de volonté et de ne pas distinguer, en essence, sa volonté de la mienne" (99) there is not a hint of condescension in his appreciation of Césaire's gifts. He is less "introducing" the poet than celebrating him and learning from him, less summarizing his Cahier than directing potential readers toward it. In an early example of what the Kenyan novelist and critic Ngugi wa Thiong'o terms "moving the center," Breton affirms the superiority of Césaire's magazine Tropiques to anything being produced in the colonial metropole, "qui portait la marque du masochisme quand ce n'était pas celle de la servilite" (94), as well as the power of the poet's words to rescue him from the despair of the involuntary exile and to make him feel once again at home in the world: "Il fallait que le monde ne fût pas en perdition: la conscience lui reviendrait" (95). 
By letting himself be guided by Césaire's insights, Breton reformulates and radicalizes his basic principles, extending them to an eloquent, prophetic, but above all empathetic condemnation of racism and colonialism which moves back in time and space to the Middle Passage origins: "...ici la plaie se rouvre, elle se rouvre de toute la grandeur de l'Afrique perdue, du souvenir ancestral des abominables traitements subis, de la conscience d'un déni de justice monstrueux et à jamais irréparable dont toute une collectivité a été victime" (104-105).

From there, it is a short step to anticipating a possible anti-colonial revolution in the event the end of the war does not bring significant change to the colonized peoples both inside and outside the metropoles: "force serait de se ranger définitivement, avec toutes les implications que cela comporte, à l'opinion que l'émancipation des peuples de couleur ne peut être que l'oeuvre de ces peuples eux-mêmes" (106). For Breton, this was not mere rhetoric; at the end of the war, before returning to France, he stopped over in Haiti and made several speeches to groups of sympathizers and to mass student gatherings. Recalling one of these speeches in an interview, he said, "Force me fut, en terminant, d'incriminer 'les impérialismes nullement conjurés de cette fin de guerre et ce jeu de la souris avec le chat qui se poursuit cruellement entre les idéaux proclamés et les égoïsmes éternels"' (Breton 1969, 247). This particular speech encouraged the editors of a student paper -including the poets René Depestre and Paul Laraque- to begin an agitation that culminated in a general strike and the fall of the government. Characteristically, Breton played down the role of instigator and gave all the credit to the movement itself.

This insistence on the need for the colonized peoples to determine their own course of action characterized Breton's own approach to surrealist sympathizers in Latin America and the Caribbean. As Bernard Mouralis remarks, "Le surréalisme n'était ni un parti, ni un impérialisme. Et cela explique sans doute la nature des liens qui se sont établis entre surréalistes et écrivains noirs" $(1984,163)$. In one of his Haitian speeches, Breton, while affirming the existence of a spiritual interdependence among peoples, admits to a certain unease at importing surrealism from the outside, given its origins in different social and cultural circumstances from those of his audience: "It is up to you...to convince me that the surrealist message could be absorbed by you" $(1978,259)$.

Paraphrasing Aimé Césaire, surrealism in the Americas acted less as a revelation than a confirmation. In other words, the practical and imaginative bases which surrealism had with much effort endeavored to build in a European context had long existed in a New World whose history had in large part been created in and through a mortal conflict between the poetic cosmologies of the indigenous civilizations and the utilitarian, Christo-mercantile myths of a Western civilization which, virtually from the moment it stumbled onto American shores, revealed its worst qualities. The Barbadian poet Kamau Brathwaite has conceptualized the appearance of the West in the Americas as an "alter-Renaissance," a process that transformed Shakespeare's Prospero from an Old World magus into a New World slave-master intent on the complete subjugation of nature and those "savages" who dwelled within it. The syncretic cultures and mythologies that emerged from the individual and collective resistance of those Africans trans- 
ported en masse as chattels to American shores testified to the endurance -indeed, the existential necessity - of a poetic impulse that drew from the clandestine interplay of besieged memories and harrowing experiences a convulsive, exploding-fixed beauty. Critics and musicologists have pointed out, for example, the manifestly surrealist content of blues lyrics, and the linguistic extravagance of certain popular African-American tales, rhymes, and legends is fully as delirious (and equally as sophisticated) as anything by, say, Benjamin Péret. In that respect, this diasporic culture of cultures can be said to be closer to the mythopoetic sources of which Breton and the surrealists spoke than are those who have to divest themselves of inculcated layers of "civilization" in order to hear the voices within.

To the extent that the surrealist message provided its American auditors with a specific conception and practice of poetry founded on the will to transform the individual and collective experience of daily life, to that extent was it enthusiastically taken up and developed, even by those who remained outside the organized movement proper. A significant example of this surrealist influence emerges from an essay written by Ralph Ellison in 1948, three years after André Breton left the New World, and around the time Ellison himself was beginning work on his Invisible Man, a novel that, along with Moby-Dick, would convey the fullest mythic picture yet written of the syncretically surreal civilization of civilizations still struggling to be born in the United States. This essay, which was rejected for magazine publication, contains the following revelatory words about his neighborhood, where he remained until his death in 1994:

This abruptness of change and the resulting clash of cultural factors within Negro personality account for some of the extreme contrasts found in Harlem, for both its negative and positive characteristics. For if Harlem is the scene of the folk-Negro's death agony, it is also the scene of his transcendence. (...) It explains the nature of a world so fluid and shifting that often within the mind the real and unreal merge, and the marvelous beckons from behind the same sordid reality that denies its existence. (Ellison $1966,284)$

\section{Works Cited}

Baciu, Stefan (ed.). 1974. Antologia de la poesia surrealista latinoamericana. Mexico City: Joaquín Mortiz.

Breton, André. 1962. Manifestes du surréalisme. Paris: Jean-Jacques Pauvert.

—1967. La clé des champs. Paris: Jean-Jacques Pauvert.

-1969. Entretiens (1913-1952). Paris: Gallimard.

-1970. Perspective cavalière. Ed. Marguerite Bonnet. Paris: Gallimard.

—. 1972a. Martinique charmeuse de serpents. Paris: Jean-Jacques Pauvert.

__ 1972b. Surrealism and Painting. Tr. Simon Watson Taylor. New York: Harper \& Row.

-1978. What is Surrealism? Selected Writings. Ed. and intro. Franklin Rosemont. New York: Monad.

Ellison, Ralph. 1966. Shadow and Act. New York: Signet. 
Mabille, Pierre. 1977. Le merveilleux. Paris: Pierre Jean Oswald. 1981. Messages de l'étranger. Paris: Plasma.

Monnerot, Jules. 1945. La poésie moderne et le sacré. Paris: Gallimard.

Mouralis, Bernard. 1984. Littérature et développement. Paris: Silex Editions.

Péret, Benjamin (intro. and ed.). 1960. Anthologie des mythes, légendes et contes populaires d'Amérique. Paris: Albin Michel.

Price-Mars, Jean. 1990. So Spoke the Uncle. Tr. and intro. Magdaline W. Shannon. Washington, D.C.: Three Continents. 